\title{
Customers' Continuance Intention in Using a Mobile Navigation App in the Tourism Context: What Factors Will Lead?
}

\author{
Usep Suhud \\ Universitas Negeri Jakarta, Indonesia \\ usuhud@unj.ac.id \\ Mamoon Allan \\ The University of Jordan, Jordan \\ m.allan@ju.edu.jo \\ Dian Puspita Sari \\ Universitas Negeri Jakarta, Indonesia \\ dianpuspitao4@gmail.com

\section{Bayu Bagas Hapsoro} \\ Universitas Negeri Semarang, Indonesia \\ bbhapsoro@mail.unnes.ac.id

\section{Dorojatun Prihandono} \\ Universitas Negeri Semarang, Indonesia \\ dprihandono@mail.unnes.ac.id
}

A mobile navigation app with a geographical information system is favoured to search addresses and find the fastest ways to reach a destination. However, there is a lack of scholarly attention to consumer behaviour and mobile navigation apps. This study aims to measure the impact of perceived enjoyment, perceived usefulness, customer satisfaction, and customer habit on continuance intention to use a mobile navigation app. Data were collected using an electronic survey; participants were approached by applying a convenient sampling method. According to Burns and Grove (2005, p. 351), 'Convenience sampling is useful for descriptive and correlation studies conducted in new areas of research.' In total, 212 participants were involved in this study, consisting of 110 females and 102 males. This study found that Google Maps and Waze were the most popular apps used by participants. Perceived enjoyment had a significant impact on perceived usefulness and habit. Perceived usefulness had a substantial effect on satisfaction. Satisfaction significantly influenced continuance intention. In addition, customer habit significantly affected satisfaction and continuance intention. This study discusses recommendations for future research.

Keywords: continuance intention, customer habit, geographical information system (GIs), Google Maps, mobile navigation application, technology adoption, tourism, Waze 


\section{Introduction}

Modern humans increasingly rely on mobile technologies and a geographic information system (GIS) such as Google Maps, Waze, and similar applications (apps) (Brumen et al., 2020; Dickinson et al., 2016). These apps have been adopted by motorcyclists, pedestrians, and people with special needs (Mikayelyan, 2011). Generally, Google Maps and Waze are the two most popular navigation apps in Indonesia. Although both are used as a driving guide, Google Maps and Waze have clear differences.

First, according to Alfarizi (2020), Google Maps features a right-click option, which navigates to selected destinations and measures the distance between two points on the map. Second, Google Maps users can touch the screen to zoom in on an image. Third, the app provides statistical data about peak hours, helping users avoid long queues. Fourth, Google Maps can recall parking spots. Fifth, the app does not require users to meet a quota. Finally, Google Maps users can share their location(s) and view usage history.

Several studies have explored consumer behaviour and mobile navigation apps. For example, Marzuki et al. (2016) measured intention to use online mapping by employing perceived interactivity, perceived ease of use, perceived usefulness, and perceived enjoyment. Noerkaisar et al. (2016) used the awareness, interest, desire, and action (AIDA) formula in relation to the Waze app. Another study by Knote and Söllner (2017) focused on the e-service quality of three apps. Moorthy et al. (2019) examined influencing factors of behavioural intention to adopt mobile apps, selecting performance expectancy, habit, price value, social influence, complexity, and trialability as predictors. To support the current study, the authors also use theories from other relevant studies to form a theoretical framework. These include e-payment, mobile social networking, and other mobile services (Gan et al., 2017; Tella \& Olasina, 2014; Wang et al., 2016). In the tourism sector, it is still difficult to find studies that measure consumer behaviour related to navigation apps. Therefore, this study will be significant in filling the gap.

As noted, few studies were found on the use of mobile navigation apps. Therefore, this study aims to measure factors that impact the continuance intention of users. This study includes perceived enjoyment, perceived usefulness, customer satisfaction, and habit as predictor factors.

\section{Literature Review}

Perceived Enjoyment

Overall, enjoyment refers to pleasure, joy, or delight. One could find pleasure when they use a certain gadget or app. Kimiecik and Harris (1996) defined enjoyment as 'an optimum psychological state (i.e., flow) that leads to performing an activity primarily for its own sake and is associated with positive affective experiences' (para. 1). Further, enjoyment should contain affect, pleasure, attitude, intrinsic motivation, and enjoyment flow.

Depending on the context, enjoyment can cause and be caused by different factors. For example, in game play, enjoyment can be affected by competence, autonomy, and relatedness (Tamborini et al., 2010), as well as knowledge sharing (Binsawad et al., 2016). In general, enjoyment can impact attitude, perceived usefulness, habit, and continuance intention (Mouakket, 2015; Phan \& Daim, 2011; Tella \& Olasina, 2014). Previous studies claim that perceived enjoyment is an important factor in shaping perceived usefulness (Alsultanny \& Alotaibi, 2015; Aziz \& Lei, 2016; Lee, 2021; Ngangi \& Santoso, 2019; Ongena et al., 2013). For example, Ongena et al. (2013) selected perceived enjoyment as a variable to predict behavioural intention in the context of an audio-visual heritage archive. Their study found that perceived enjoyment significantly affects perceived usefulness. Accordingly, Aziz and Lei (2016) focused on the behavioural intention of Chinese youth consumers to play a mobile game. Perceived enjoyment was linked to perceived usefulness. Based on their analysis, they demonstrate that perceived enjoyment has a significant effect on perceived usefulness. Furthermore, Alsultanny and Alotaibi (2015) included perceived enjoyment in investigating factors that influence the behavioural intention of human resource development (HRD) in organisations to employ online recruitment for new employees. They also prove that perceived enjoyment has a significant effect on perceived usefulness. Addition- 
ally, Ngangi and Santoso (2019) tested the implementation of a customer relationship management system in automotive companies. Perceived enjoyment is considered an important variable to predict user behaviour. They claim that perceived enjoyment significantly affects perceived usefulness.

Consequently, the following hypothesis was formulated:

$\mathrm{H} 1$ Perceived enjoyment will have a significant effect on perceived usefulness in using a mobile navigation app on a daily basis.

Phan and Daim (2011), after examining factors that influence mobile service use intention, found that enjoyment significantly influenced perceived usefulness. However, in the current study, the authors use perceived enjoyment, linking this variable to perceived usefulness and habit. In the same vein, Turel and Serenko (2012) measured factors that affect the addiction of social networking website users. They argued that individuals who have higher perceived enjoyment will form a strong habit in using the website. A similar result was found by Hsiao et al. (2016), mentioning that perceived enjoyment has a significant impact on habit.

Based on this discussion, the authors hypothesise the following:

$\mathrm{H} 2$ Perceived usefulness will have a significant effect on the habit of using a mobile navigation app daily.

\section{Perceived Usefulness}

Davis (1989) defined perceived usefulness as 'the degree to which a person believes that using a particular system would enhance his or her job performance' (p. 320). Jahangir and Begum (2008) described the perceived usefulness concept as 'the degree to which a person believes that using a particular system would enhance his or her job performance' ( $p$. 33). Perceived usefulness predicts perceived benefit, satisfaction, continuance intention, perceived ease of use, and actual use (Tella \& Olasina, 2014; Wang et al., 2016).

In the current study, perceived usefulness is linked to customer satisfaction. A study by Amin et al. (2014) explored the satisfaction of mobile website users. The study employed perceived ease of use, perceived usefulness, and trust to predict satisfaction, noting a significant impact of perceived usefulness on mobile user satisfaction. Further, Sibona and Choi (2012) investigated the satisfaction of Facebook users, linking perceived ease of use to perceived usefulness and satisfaction, as well as linking perceived usefulness to satisfaction. Their study documented a significant impact of perceived usefulness on satisfaction.

The satisfaction of smart plug users in the United Arab Emirates was studied by Ghazal et al. (2016). Their study employed environmental concern, app usage characteristics, information quality, importance, and app usefulness. One finding is a significant influence of usefulness on satisfaction.

Shah and Attiq (2016) employed technology quality, perceived ease of use, and perceived usefulness to test the satisfaction of e-learning consumers. Their study involved university students in Pakistan. One finding showed that perceived usefulness has a significant impact on consumer satisfaction. The same result is demonstrated by Joo et al. (2017), Mouakket (2015), and Wang et al. (2016), indicating a significant effect of perceived usefulness on customer satisfaction.

Therefore, the third hypothesis is formulated as follows:

$\mathrm{H} 3$ Perceived usefulness will have a significant effect on customer satisfaction in using a mobile navigation app on a daily basis.

\section{Satisfaction}

In the context of retail banking services, Caruana (2002, p. 816) defined customer satisfaction as:

[A] post purchase, global affective summary response, that may be of different intensities, occurring when customers are questioned and undertaken relative to the retail banking services offered by competitors.

This definition can be adapted into the setting of mobile navigation services. Satisfaction can be reached after users adopt mobile navigation technology. In addition, users show devotion by choosing one app from 
among the others. Generally, customer satisfaction can predict habit, continuance intention, and continuance behaviour (Bhattacherjee \& Lin, 2015; Limayenm et al., 2003; Wang et al., 2016).

In Korea, Ohk et al. (2015) examined continuance intention to use the Korean government's mobile apps, finding that satisfaction has a significant effect on continuance usage intention. In Kenya, Osah and Kyobe (2017) looked at the continuance intention of users of M-Pesa, a mobile money system for microscale businesses and lower-income families. They questioned whether satisfaction has a direct impact on continuance intention, indicating a significant and direct effect of satisfaction on continuance intention. Similarly, Amoroso and Lim (2017), Joo et al. (2017), Mark and Vogel (2009), Mouakket (2015), and Wang et al. (2016) investigated the role of satisfaction in continuance intention, showing a significant effect of customer satisfaction on continuance intention.

Based on these studies, the fourth hypothesis is as follows:

H4 Customer satisfaction will have a significant impact on continuance intention to use a mobile navigation app on a daily basis.

Shiau and Luo (2013) mentioned that those who are consistent with their habit tend to be satisfied in using mobile social networking. Furthermore, Wang et al. (2013) tested factors that could influence consumers to use self-service technology in supermarkets. One hypothesis tested whether customer satisfaction could affect habits, suggesting that customer satisfaction has a significant effect on consumer habits in the use of self-service technology. Amoroso and Lim (2017) examined influencing factors of continuance intention, presenting one finding that satisfaction significantly influenced habit. Moreover, Chiu et al. (2012) focused on online shoppers' intention to repurchase, postulating that satisfaction significantly affects habit. Relatedly, Gu et al. (2019) measured Chinese consumers' continuance intention to use a smart home service. As a result, satisfaction is a significant variable to predict consumers' habits.

The following hypothesis was guided by the above studies:
H5 Habit will have a significant impact on customer satisfaction in using a mobile navigation app on a daily basis.

Habit

In general, habit is a custom, lifestyle, norm, pattern, behaviour, belief, tradition, and/or character of a person. According to Shiau and Luo (2013, p. 576), 'habits reflect automatic behaviour tendencies developed during the past history of the individual.' Habit can enhance customer loyalty, satisfaction, purchase behaviour, and continuance intention (Guo \& Barnes, 2012; Hsiao et al., 2016; Yee \& Faziharudean, 2010). Amoroso and Lim (2017) and Wang et al. (2016) linked satisfaction to habit. However, in the current study, habit is linked to continuance intention.

\section{Habit and Continuance Intention}

Habit is included in prior studies that examined customers' continuance intention to use certain services. Rahardja et al. (2019) reported that habit supports intention to continue using a mobile game learning service. Also, Gan et al. (2017) and Wang et al. (2016) claimed that habit has a significant impact on intention to use a social networking service. Habit is also employed by Liao et al. (2006) and Liu et al. (2018), investigating factors influencing continuance intention to shop online and make online investments, respectively. They show a significant influence of habit on continuance intention. Furthermore, a study to measure customers' intention to continue using a music streaming service was conducted by Wulandari et al. (2019). It was found that habit has a significant impact on continuance intention.

Considering the discussion above, the following hypothesis must be examined:

H6 Habit will have a significant impact on continuance intention to use a mobile navigation app on a daily basis.

\section{Theoretical Framework}

Figure 1 shows the model and theoretical framework to be tested. Perceived enjoyment is linked to perceived usefulness and habit. Further, perceived usefulness is 


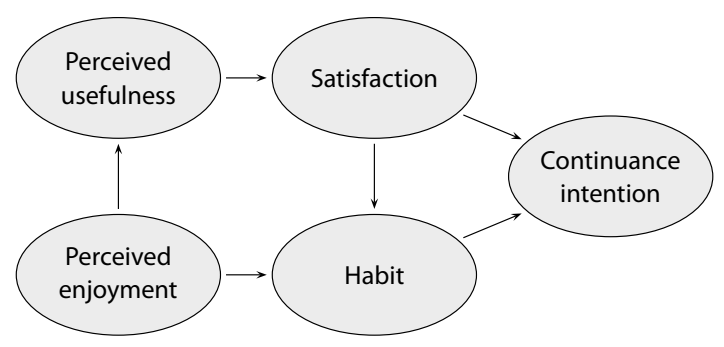

Figure 1 Theoretical Framework

connected to customer satisfaction. Customer satisfaction is linked to habit and continuance intention. Additionally, habit is used to predict continuance intention.

\section{Methods}

Sample

The study expected a minimum of 200 participants to be involved. With this number, the authors can determine the minimum loading factor of 0.4 , showing the validity of each indicator (Hair et al., 2019). A convenient sampling method was employed in this study. The following criteria were selected as a cohort for the current study:

1. Participants were identified as those who drove a motorcycle and/or car to work or campus daily.

2. Participants have installed and used a navigation app on their vehicle. Prospective participants who met the criteria were asked to fill out an online questionnaire.

Willing participants were sent a link to the survey. Private messages and questionnaire links were sent via WhatsApp and Line. Data were collected in Jakarta, Indonesia.

\section{Measures}

The authors adapted indicators from the studies of Dang and Nguyen (2015) and Hsiao et al. (2016) to measure perceived enjoyment. Further, indicators from Oghuma et al. (2016) and Wang et al. (2016) were adapted to examine perceived usefulness. Indicators from Hsiao et al. (2016), Shiau and Luo (2013), and Wang et al. (2016) were used to measure habit. Indicators from Dang and Nguyen (2015), Hsiao et al.
(2016), and Shiau and Luo (2013) were adapted to measure customer satisfaction. Lastly, the authors adapted indicators from Dang and Nguyen (2015) and Hsiao et al. (2016) to test continuance intention. Indicators were translated into Bahasa (language) Indonesia for the survey. The questionnaire was made with Google Forms and distributed via an instant messenger platform. The authors adopted a snowball sampling method by persuading respondents to spread the questionnaire link to their networks.

\section{Data Analysis}

The authors analysed the data in three steps. First, an exploratory factor analysis (EFA) used direct oblimin rotation to validate dimensions and indicators. Second, a reliability test was conducted. Third, a structural equation model was used to measure the proposed research framework. The author selected four criteria as requirements for a fitted model.

1. Probability score of $\geq 0.05$ (Schermelleh-Engel et al., 2003).

2. CMIN/DF score of $\leq 2$ (Tabachnick et al., 2007).

3. CFI score of $\geq 0.97$ (Hu \& Bentler, 1995).

4. RMSEA score of $\leq 0.05$ (Hu \& Bentler, 1999).

\section{Results and Discussion}

Participants

This study involved 212 participants, including 102 males (48.1\%) and 110 females (51.9\%). Table 1 shows the profile of the participants. In terms of age, most participants were 21 to 24 years of age.

Additionally, participants indicated that 155 (73.1\%) had a two-wheeled vehicle, 34 (16.1\%) had two- and four-wheeled vehicles, and $23(10.8 \%)$ had a fourwheeled vehicle. When asked about GIs, participants used the most frequent apps; 167 (78.8\%) marked Google Maps and 44 (20.8\%) used Waze. One participant (0.5\%) chose the HERE WeGo app.

\section{EFA}

Table 3 (see p. 143) shows the EFA result of all variables in this study. Perceived enjoyment possessed five indicators with a Cronbach's alpha score of 0.898 , with factor loadings ranging from 0.603 to 0.829 . Perceived 
Table 1 Profile of Participants

\begin{tabular}{|c|c|c|c|}
\hline Category & Item & Frequency & Percent \\
\hline \multirow[t]{3}{*}{ Sex } & Male & 102 & 48.1 \\
\hline & Female & 110 & 51.9 \\
\hline & Total & 212 & 100.0 \\
\hline \multirow[t]{6}{*}{ Age } & $<20$ & 30 & 14.2 \\
\hline & $21-25$ & 115 & 54.2 \\
\hline & $26-30$ & 59 & 27.8 \\
\hline & $31-35$ & 4 & 1.9 \\
\hline & $36-40$ & 3 & 1.4 \\
\hline & $41-45$ & 1 & 0.5 \\
\hline \multirow{3}{*}{$\begin{array}{l}\text { Occupational } \\
\text { status }\end{array}$} & Employed & 131 & 61.8 \\
\hline & Unemployed & 118 & 31.6 \\
\hline & Self-employed & 14 & 6.6 \\
\hline \multirow{5}{*}{$\begin{array}{l}\text { Level of } \\
\text { education } \\
\text { completed }\end{array}$} & Diploma & 49 & 23.1 \\
\hline & Undergraduate & 86 & 40.6 \\
\hline & Postgraduate & 5 & 2.4 \\
\hline & High school & 67 & 31.6 \\
\hline & Less than high school & 5 & 2.4 \\
\hline
\end{tabular}

Table 2 Vehicle and Mobile Navigation App Ownership

\begin{tabular}{llrr}
\hline Category & Item & Frequency & Percent \\
\hline Type of vehicle & Two-wheeled vehicle & 155 & 73.1 \\
ownership & Two-wheeled and & 34 & 16.1 \\
& four-wheeled vehicle & & \\
& Four-wheeled vehicle & 23 & 10.8 \\
\hline Application & Google Maps & 167 & 78.8 \\
& HERE WeGo & 1 & 0.5 \\
& Waze & 44 & 20.8 \\
\hline
\end{tabular}

usefulness had six items, with factor loadings ranging from 0.693 to 0.835 . This construct had a Cronbach's alpha score of 0.880 . Further, habit, customer satisfaction, and continuance intention survived six indicators, with Cronbach's alpha scores of $0.899,0.908$, and 0.898 , respectively. All constructs were considered reliable with a Cronbach's alpha score of 0.8 and larger.

\section{Hypotheses Testing}

Figure 2 demonstrates the result of the structural equation model. This model achieved a fitness with a prob- ability score of 0.112, a CMIN/DF score of 1.228, a CFI score of 0.990 , and a RMSEA score of 0.033 .

Table 4 (see p. 144) reports the results summary of the hypotheses testing. In total, there were six hypotheses. Five of the hypotheses $\left(\mathrm{H}_{1}, \mathrm{H}_{3}, \mathrm{H} 4, \mathrm{H} 5\right.$, and H6) had a critical ratio (CR) score larger than 2.0, indicting significances.

\section{Discussion}

This study evaluated factors that influence continuance intention to utilize a mobile navigation app. The first hypothesis predicted the influence of perceived enjoyment on perceived usefulness. Users with positive enjoyment perceptions of mobile navigation apps view these apps as beneficial. This path had a CR score of 5.263, indicating significance. This finding supports previous studies, such as Alsultanny and Alotaibi (2015), Aziz and Lei (2016), Ngangi and Santoso (2019), and Ongena et al. (2013).

The second hypothesis predicted the impact of perceived enjoyment on habit. Online directions apps can be influenced by several factors, including perceived enjoyment (Hsiao et al., 2016; Phan \& Daim, 2011; Turel \& Serenko, 2012). The path gained a CR score of 1.843 , showing insignificance. Perceived enjoyment failed to predict habit.

The third hypothesis focused on the impact of perceived usefulness and customer satisfaction. This path has been explored (Amin et al., 2014; Ghazal et al., 2016; Shah \& Attiq, 2016; Sibona \& Choi, 2012). Users who perceive that a mobile navigation app has high usability tend to be satisfied with the performance of the app. In this case, the path achieved a CR score of 8.364. This was the highest score among the others.

The fourth hypothesis measured the impact of satisfaction on continuance intention. Consumers who are satisfied with a technology-based product tend to continue their intention to use the product. This satisfaction can be influenced by many factors, including attitude, social ties, perceived enjoyment, perceived value, perceived ease of use, and perceived usefulness (Hsiao et al., 2016; Hsu \& Lin, 2016; Lee et al., 2015; Newholm \& Shaw, 2007). In this case, the navigation app gives satisfaction to its users. This satisfaction is influenced by perceived usefulness. The 
Table 3 EFA Results

\begin{tabular}{|c|c|c|}
\hline Indicators & $(1)$ & $(2)$ \\
\hline Perceived enjoyment & & 0.778 \\
\hline EN2 Using a mobile navigation app is great fun. & 0.829 & \\
\hline EN 5 I am interested in using a mobile navigation app. & 0.827 & \\
\hline EN1 I am more comfortable using a mobile navigation app in searching for a location. & 0.782 & \\
\hline EN4 In my opinion, a mobile navigation app has many features. & 0.605 & \\
\hline EN3 In my opinion, a mobile navigation app features information sharing facilities. & 0.603 & \\
\hline Perceived usefulness & & 0.880 \\
\hline PU4 A mobile navigation app is an efficient use of my time. & 0.835 & \\
\hline PU 3 I find the mobile navigation app to be beneficial. & 0.820 & \\
\hline PU 5 Using a mobile navigation app makes doing things effortless. & 0.815 & \\
\hline PU 2 Using a mobile navigation app is more effective than other ways. & 0.805 & \\
\hline PU6 A mobile navigation app is more profitable than other ways. & 0.782 & \\
\hline PU 1 A mobile navigation app is very useful in my everyday life. & 0.693 & \\
\hline Habit & & 0.899 \\
\hline HA1 Using a mobile navigation app became a habit for me. & 0.864 & \\
\hline HA 2 I have to use a mobile navigation app. & 0.851 & \\
\hline HA 4 I became dependent on using a mobile navigation app. & 0.843 & \\
\hline $\mathrm{HA}_{3}$ Using a mobile navigation app is already natural to me. & 0.825 & \\
\hline HA 5 When faced with location searching, I automatically use a mobile navigation app. & 0.759 & \\
\hline HA6 When faced with location searching, using a mobile navigation app is the right choice for me. & 0.753 & \\
\hline Customer satisfaction & & 0.908 \\
\hline SA3 My experience with using a mobile navigation app was very satisfying. & 0.871 & \\
\hline SA 1 I am delighted with my choice of a mobile navigation app in location searching. & 0.866 & \\
\hline sA4 I think I made the right decision in using a mobile navigation app. & 0.848 & \\
\hline SA2 I am happy with my decision on choosing a mobile navigation app. & 0.833 & \\
\hline SA 5 I am satisfied with downloading a mobile navigation app. & 0.819 & \\
\hline s A6 I am thrilled with the features in a mobile navigation app. & 0.732 & \\
\hline Continuance intention & & 0.898 \\
\hline CON4 I believe I will keep using a mobile navigation app. & 0.906 & \\
\hline CON 2 I will use a mobile navigation app in my daily life. & 0.835 & \\
\hline CON3 I will continue to use a mobile navigation app later on. & 0.832 & \\
\hline CON1 I intend to continue using a mobile navigation app. & 0.802 & \\
\hline con6 I would recommend a mobile navigation app to anyone interested in location searching. & 0.773 & \\
\hline CON 5 I believe my interest will increase in the future toward updating a mobile navigation app's feature & 0.738 & \\
\hline
\end{tabular}

Notes Column headings are as follows: (1) factor loadings, (2) Cronbach's alpha.

current study shows that customer satisfaction affects continuance intention as documented by prior studies
(Gan et al., 2017; Ohk et al., 2015; Osah \& Kyobe, 2017). The fifth hypothesis predicted that satisfaction af- 


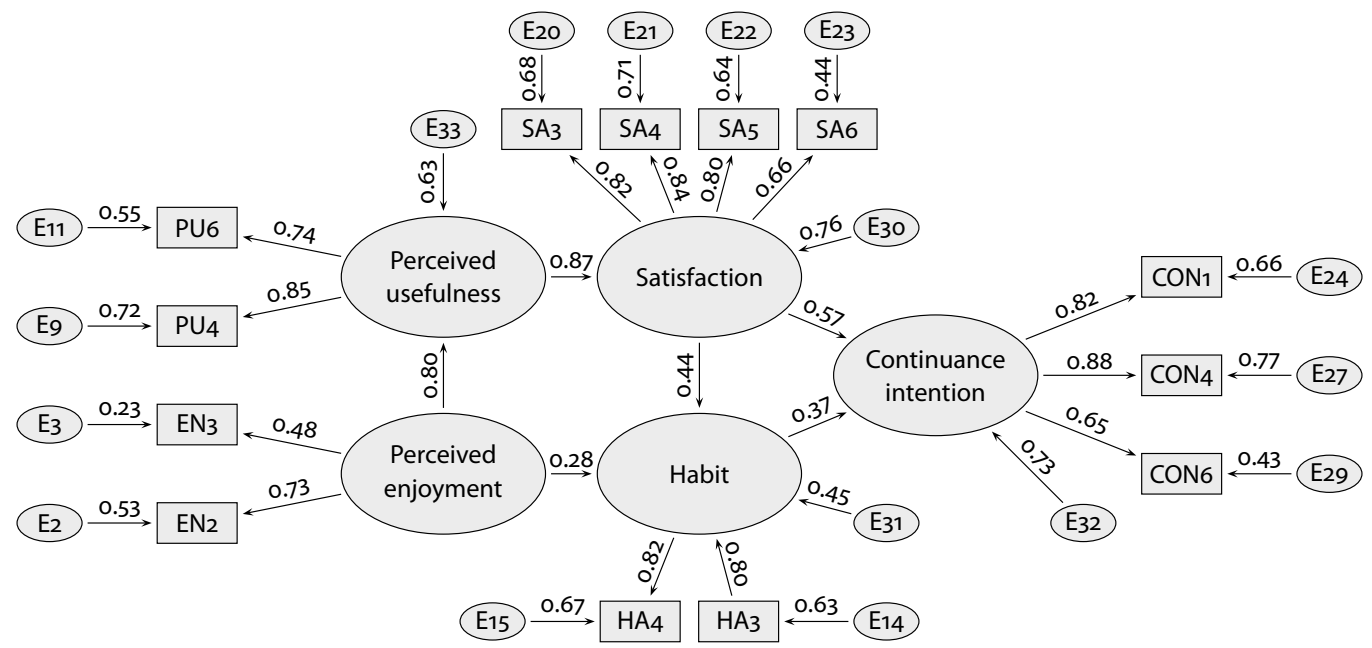

Figure 2 Structural Model of the Proposed Model

Table 4 Result Summary of Hypotheses Testing

\begin{tabular}{|c|c|c|c|c|c|}
\hline \multicolumn{3}{|c|}{ Hypotheses/paths } & \multirow{2}{*}{$\begin{array}{l}\text { CR } \\
5.263\end{array}$} & \multirow{2}{*}{$\frac{P}{* * *}$} & \multirow{2}{*}{$\frac{\text { Results }}{\text { Accepted }}$} \\
\hline $\mathrm{H} 1$ & Perceived enjoyment & $\rightarrow$ Perceived usefulness & & & \\
\hline $\mathrm{H} 2$ & Perceived enjoyment & $\rightarrow$ Habit & 1.841 & 0.066 & Rejected \\
\hline $\mathrm{H} 3$ & Perceived usefulness & $\rightarrow$ Satisfaction & 8.364 & $* * *$ & Accepted \\
\hline $\mathrm{H} 4$ & Satisfaction & $\rightarrow$ Continuance intention & 6.188 & $* * *$ & Accepted \\
\hline $\mathrm{H} 5$ & Satisfaction & $\rightarrow$ Habit & 3.250 & 0.001 & Accepted \\
\hline н 6 & Habit & $\rightarrow$ Continuance intention & 4.294 & $* * *$ & Accepted \\
\hline
\end{tabular}

fected habit in using a directional app. When a person has a habit of using a tool, gadget, or app, this behaviour can be a manifestation of intentional or unintentional spontaneity, whether planned or unplanned and/or realized or not realized. Prior studies (Amoroso \& Lim, 2017; Chiu et al., 2012; Shiau \& Luo, 2013) convinced us about the importance of habit and satisfaction. The current study indicates the same finding with a CR score of 3.250 .

The last hypothesis predicted the impact of habit on continuance intention. The current study found a significant impact of habit on continuance intention with a CR score of 4.294 (Gan et al., 2017; Liao et al., 2006; Liu et al., 2018; Rahardja et al., 2019; Wang et al., 2013; Wulandari et al., 2019). When using a mobile navigation app as a habit, consumers will continue to use the app. Even with usual routes, users will continue to use the app because of their familiar behavioural reflex.

\section{Conclusion}

This study aimed to measure the impact of perceived usefulness, consumer satisfaction, and habit on the intention to continue using a mobile navigation app. In this case, participants predominantly used Google Maps. The study found a significant impact of perceived usefulness on satisfaction, of habit on satisfaction and continuance intention, and of satisfaction on habit. The authors predict that if GIS is used to help users while driving a vehicle, both car and motorcycle use will increase, especially in large cities with high traffic congestion levels. 
Although it does not directly affect continuance intention, the service provider needs to apply the Signpost app to pay attention to the users' perceived enjoyment of the app.

In some studies, the use and intentions regarding gadgets and social media are influenced by perceived enjoyment. The authors believe that GIs should not be integrated with a social media platform. When using Waze, for example, users will see their friends in the network who are also using Waze. We should not allow the user to have an interactive conversation with other users because of the risk of disrupting user concentration while driving their vehicles.

From the results of this study, perceived usefulness affects customer satisfaction. Previous studies relating to the use of gadgets, social media, and customer satisfaction are also affected. The study shows a significant impact of customer satisfaction on habits. This evidence indicates that customers will make the use of GIS a habit, meaning there is a tendency to bond between users and GIS. Other research can explore this aspect for attachment level and attachment impact to continuance intention and customer loyalty to certain GIS providers.

This study helps to expand our knowledge about technology adoption of the mobile navigation app. It also serves as a sturdy base for future studies in different contexts, settings, and countries. Moreover, it helps us better understand the behaviour of users of mobile navigation apps, which will aid in consumer retention. It could help service providers, planners, managers, and marketers enhance the user experience in the mobile navigation app context.

It has been mentioned that it is difficult to find studies that reveal consumer behaviour related to navigation apps. The findings of this study prove that technology adoption theories can also be applied to the adoption of navigation apps; they have succeeded in filling the gaps in marketing, tourism, and tourism marketing.

Future studies can further reveal the role of factors that can measure continuance intention to use navigation apps by consumers and tourists, including usage intention, usage behaviour, usage decision, and loyalty. In addition, future studies should consider the selection of variables, looking at sample groups like younger vs. older people, men vs. women, and professionals vs. non-professionals. Several studies have shown that demographic factors play a role in technology adoption (Bhandari, 2019; Haider et al., 2018; Ooi et al., 2020). Furthermore, future studies can focus on the types of vehicles used and whether they are in the city of domicile or travelling out of town.

\section{Limitations of the Study}

However, the authors recognise several limitations of this study. For example, the current study used a convenient sampling method, which, at its root, is a nonprobability sampling method. With a population of Jakarta that exceeds 50 million, the number of 212 participants will not be sufficient. Therefore, the results of this study are not intended to generalise the findings; they are only directed to fill existing research gaps. Another limitation of this study was that the authors did not anticipate that most participants would be motorcyclists. The authors suspect that there might be differences in results if the survey balanced the numbers between the motorcyclist and motorist participants.

\section{References}

Alfarizi, M. K. (2020, February 7). Genap 15 tahun, Google Maps hadirkan ikon dan fitur baru. Tempo.Co. https:// tekno.tempo.co/read/1304776/genap-15-tahun-google -maps-hadirkan-ikon-dan-fitur-baru/full\&view $=$ ok

Alsultanny, Y. A., \& Alotaibi, M. F. (2015). Evaluating the factors affecting on intension to use of e-recruitment. American Journal of Information Science and Computer Engineering, 1(5), 324-331.

Amin, M., Rezaei, S., \& Abolghasemi, M. (2014). User satisfaction with mobile websites: The impact of perceived usefulness (PU), perceived ease of use (PEOU) and trust. Nankai Business Review International, 5(3), 258-274.

Amoroso, D., \& Lim, R. (2017). The mediating effects of habit on continuance intention. International Journal of Information Management, 37(6), 693-702.

Aziz, B. G. A., \& Lei, S. (2016). Yan'An mobile game player's consumption concept of Donghua University Campus. Journal of Service Science and Management, 9, 292-302.

Bhandari, A. (2019). Gender inequality in mobile technology access: The role of economic and social development. Information, Communication \& Society, 22(5), 678-694. 
Bhattacherjee, A., \& Lin, C.-P. (2015). A unified model of IT continuance: Three complementary perspectives and crossover effects. European Journal of Information Systems, 24(4), 364-373.

Binsawad, M., Hawryszkiewycz, I., \& Kang, K. (2016). The influence of the knowledge-sharing process on technology business incubator performance in Saudi Arabia. In J. Gołuchowski, M. Pańkowska, C. Barry, M. Lang, H. Linger \& C. Schneider (Eds.), Information systems development: Complexity in information systems development (ISD2016 Proceedings) (pp. 484-494). University of Economics in Katowice.

Brumen, B., Planinc, P., Špindler, T., Gorenak, M., \& Štuhec, T. L. (2020). Use of mobile technologies in tourism: Natural health resorts study. Mediterranean Journal of Social Sciences, 11(4), 1. https://doi.org/10.36941/mjss-202O0036

Burns, N., \& Grove, S. (2005). The practice of nursing research: Conduct, critique, and utilization. Elsevier Health Sciences.

Caruana, A. (2002). Service loyalty: The effects of service quality and the mediating role of customer satisfaction. European Journal of Marketing, 36(7/8), 811-828.

Chiu, C.-M., Hsu, M.-H., Lai, H., \& Chang, C.-M. (2012). Reexamining the influence of trust on online repeat purchase intention: The moderating role of habit and its antecedents. Decision Support Systems, 53(4), 835-845.

Dang, N. H. X., \& Nguyen, P. V. (2015). The intention to play online mobile games in Ho Chi Minh City, Vietnam. International Journal of Applied Business and Economic Research, 13(1), 363-382.

Davis, F. D. (1989). Perceived usefulness, perceived ease of use, and user acceptance of information technology. MIS Quarterly, 13(3), 319-340.

Dickinson, J. E., Hibbert, J. F., \& Filimonau, V. (2016). Mobile technology and the tourist experience: (Dis)connection at the campsite. Tourism Management, 57, 193-201.

Gan, C., Liang, X., \& Yu, X. (2017). Continuance intention on mobile social networking service: Examine the effects of habit and gratifications. In WHICEB 2017 Proceedings. https://aisel.aisnet.org/whiceb2017/44

Ghazal, M., Akmal, M., Iyanna, S., \& Ghoudi, K. (2016). Smart plugs: Perceived usefulness and satisfaction; Evidence from United Arab Emirates. Renewable and Sustainable Energy Reviews, 55, 1248-1259.

Gu, W., Bao, P., Hao, W., \& Kim, J. (2019). Empirical examination of intention to continue to use smart home services. Sustainability, 11(19), 5213. https://doi.org/10.3390 /su11195213
Guo, Y. U. E., \& Barnes, S. J. (2012). Explaining purchasing behavior within World of Warcraft. Journal of Computer Information Systems, 52(3), 18-30.

Haider, M. J., Changchun, G., Akram, T., \& Hussain, S. T. (2018). Exploring gender effects in intention to Islamic mobile banking adoption: An empirical study. Arab Economic and Business Journal, 13(1), 25-38.

Hair, J. F., Black, W. C., Babin, B. J., \& Anderson, R. E. (2019). Multivariate data analysis (8th ed.). Cengage Learning.

Hsiao, C.-H., Chang, J.-J., \& Tang, K.-Y. (2016). Exploring the influential factors in continuance usage of mobile social apps: Satisfaction, habit, and customer value perspectives. Telematics and Informatics, 33(2), 342-355.

Hsu, C.-L., \& Lin, J. C.-C. (2016). Effect of perceived value and social influences on mobile app stickiness and inapp purchase intention. Technological Forecasting and Social Change, $108(\mathrm{C}), 42-53$.

Hu, L.-T., \& Bentler, P. M. (1995). Structural equation modeling: Concepts, issues, and applications. In R. H. Hoyle (Ed.), Evaluating model fit (pp. 76-99). Sage.

Hu, L.-T., \& Bentler, P. M. (1999). Cutoff criteria for fit indexes in covariance structure analysis: Conventional criteria versus new alternatives. Structural Equation Modeling: A Multidisciplinary Journal, 6(1), 1-55.

Jahangir, N., \& Begum, N. (2008). The role of perceived usefulness, perceived ease of use, security and privacy, and customer attitude to engender customer adaptation in the context of electronic banking. African Journal of Business Management, 2(1), 32-40.

Joo, Y. J., Park, S., \& Shin, E. K. (2017). Students' expectation, satisfaction, and continuance intention to use digital textbooks. Computers in Human Behavior, 69, 83-9o.

Kimiecik, J. C., \& Harris, A. T. (1996). What is enjoyment? A conceptual/definitional analysis with implications for sport and exercise psychology. Journal of Sport and Exercise Psychology, 18(3), 247-263.

Knote, R., \& Söllner, M. (2017). Towards design excellence for context-aware services-the case of mobile navigation apps. In J. M. Leimeister \& W. Brenner (Eds.), Towards thought leadership in digital transformation: 13. Internationale Tagung Wirtschaftsinformatik (pp. 121-135). Universität St. Gallen.

Lee, J. M. (2021). Effects of the perceived usefulness and perceived enjoyment of YouTube use on academic adjustment of college students in distance education due to covid-19: Focusing on compulsive YouTube usage. Journal of the Korea Society of Computer and Information, 26(3), 137-142.

Lee, C.-Y., Tsao, C.-H., \& Chang, W.-C. (2015). The relation- 
ship between attitude toward using and customer satisfaction with mobile application services: An empirical study from the life insurance industry. Journal of Enterprise Information Management, 28(5), 680-697.

Liao, C., Palvia, P., \& Lin, H.-N. (2006). The roles of habit and web site quality in e-commerce. International Journal of Information Management, 26(6), 469-483.

Limayenm, M., Hirt, S. G., \& Cheung, C. M. K. (2003). Habit in the context of Is continuance: Theory extension and scale development. MIS Quarterly, 31(4), 705-737.

Liu, Q., Zhang, F., Mao, M., Xue, B., \& Lin, Z. (2018). An empirical study on factors affecting continuance intention of using Yu'e Bao. Tehnički vjesnik, 25(5), 1414-1420.

Mark, K.-P., \& Vogel, D. (2009). Technology support for engagement retention: The case of BackPack. Knowledge Management \& E-Learning: An International Journal, 1(3), 163-179.

Marzuki, M. I. I., Rosly, A. N., Roslan, N. S., Abdullah, D., Kamal, S. B. M., \& Azmi, A. (2016). The role of perceived interactivity, perceived ease of use, perceived usefulness, and perceived enjoyment toward intention to use online mapping service applications. International Academic Research Journal of Business and Technology, 2(2), 135-139.

Mikayelyan, E. (2011). Developing Android mobile map application with standard navigation tools for pedestrians (Student Thesis Series INES No. 224). https://lup.lub.lu.se /student-papers/search/publication/4685977

Moorthy, K., Johanthan, S., Tham, C., Xuan, K. X., Yan, L., Xunda, T., \& Sim, C. (2019). Behavioural intention to use mobile apps by gen $\mathrm{Y}$ in Malaysia. Journal of Information, 5(1), 1-15.

Mouakket, S. (2015). Factors influencing continuance intention to use social network sites: The Facebook case. Computers in Human Behavior, 53, 102-110.

Newholm, T., \& Shaw, D. (2007). Studying the ethical consumer: A review of research. Journal of Consumer Behaviour: An International Research Review, 6(5), 253-270.

Ngangi, S. C. W., \& Santoso, A. J. (2019). Customer acceptance analysis of Customer Relationship Management (CRM) systems in automotive company using Technology Acceptance Model (TAM) 2. Indonesian Journal of Information Systems, 1(2), 133-146.

Noerkaisar, N., Suharjo, B., \& Yuliati, L. N. (2016). The adoption stages of mobile navigation technology waze app as Jakarta traffic jam solution. Independent Journal of Management \& Production, 7(3), 914-925.

Oghuma, A. P., Libaque-Saenz, C. F., Wong, S. F., \& Chang, Y. (2016). An expectation-confirmation model of contin- uance intention to use mobile instant messaging. Telematics and Informatics, 33(1), 34-47.

Ohk, K., Park, S.-B., \& Hong, J.-W. (2015). The influence of perceived usefulness, perceived ease of use, interactivity, and ease of navigation on satisfaction in mobile application. Advanced Science and Technology Letters, 84, 88-92.

Ongena, G., van de Wijngaert, L., \& Huizer, E. (2013). Acceptance of online audio-visual cultural heritage archive services: A study of the general public. Information Research, 18(2). http://informationr.net/ir/18-2/paper575 .html\#.YIQNhxзiuZA

Ooi, K.-B., Foo, F.-E., Tan, G. W.-H., Hew, J.-J., \& Leong, L.Y. (2020). Taxi within a grab? A gender-invariant model of mobile taxi adoption. Industrial Management \& Data Systems, 121(2), 312-332.

Osah, O., \& Kyobe, M. (2017). Predicting user continuance intention towards M-Pesa in Kenya. African Journal of Economic and Management Studies, 8(1), 36-50.

Phan, K., \& Daim, T. U. (2011). Exploring technology acceptance for mobile services. Journal of Industrial Engineering and Management, 4(2), 339-360.

Rahardja, U., Hariguna, T., \& Aini, Q. (2019). Understanding the impact of determinants in game learning acceptance: An empirical study. International Journal of Education and Practice, 7(3), 136-145.

Schermelleh-Engel, K., Moosbrugger, H., \& Müller, H. (2003). Evaluating the fit of structural equation models: Tests of significance and descriptive goodness-of-fit measures. Methods of Psychological Research Online, 8(2), 23-74.

Shah, H. J., \& Attiq, S. (2016). Impact of technology quality, perceived ease of use and perceived usefulness in the formation of consumer's satisfaction in the context of elearning. Abasyn Journal of Social Sciences, 9(1), 124-140.

Shiau, W.-L., \& Luo, M. M. (2013). Continuance intention of blog users: The impact of perceived enjoyment, habit, user involvement and blogging time. Behaviour \& Information Technology, 32(6), 570-583.

Sibona, C., \& Choi, J. H. (2012). Factors affecting end-user satisfaction on Facebook. In Proceedings of the Sixth International A A A I Conference on Weblogs and Social Media (pp. 575-578). Trinity College Dublin, Association for the Advancement of Artificial Intelligence.

Tabachnick, B. G., Fidell, L. S., \& Ullman, J. B. (2007). Using multivariate statistics (5th ed.). Pearson.

Tamborini, R., Bowman, N. D., Eden, A., Grizzard, M., \& Organ, A. (2010). Defining media enjoyment as the satisfaction of intrinsic needs. Journal of Communication, $60(4), 758-777$.

Tella, A., \& Olasina, G. (2014). Predicting users' continuance 
intention toward e-payment system: An extension of the technology acceptance model. International Journal of Information Systems and Social Change, 5(1), 47-67.

Turel, O., \& Serenko, A. (2012). The benefits and dangers of enjoyment with social networking websites. European Journal of Information Systems, 21(5), 512-528.

Wang, C., Harris, J., \& Patterson, P. (2013). The roles of habit, self-efficacy, and satisfaction in driving continued use of self-service technologies: A longitudinal study. Journal of Service Research, 16(3), 400-414.

Wang, L., Zhao, W., Sun, X., Zheng, R., \& Qu, W. (2016). Modeling of causes of Sina Weibo continuance intention with mediation of gender effects. Frontiers in Psychology, 7, 619. https://doi.org/10.3389/FPSYG.2016.00619
Wulandari, D., Suhud, U., \& Purwohedi, U. (2019). The influence factors of continuance intention to use a music streaming application. International Journal on Advanced Science, Education, and Religion, 2(2), 17-25.

Yee, B. Y., \& Faziharudean, T. M. (2010). Factors affecting customer loyalty of using Internet banking in Malaysia. Journal of Electronic Banking Systems. https://doi.org/10 $.5171 / 2010.592297$ 